for the Conservatory's recital hall.

Publicity was handled by the Conservatory's publicity department. Promotional flyers, which encouraged donations from those not attending, were mailed to Conservatory alumni and the Friends of the Library. Newspaper announcements along with radio and television appearances by concert performers and the Conservatory librarian not only advertised the concert, but also promoted and publicized the library. Additional exposure was obtained at the concert, where four display cases highlighted the Conservatory Library collections, and handouts about the library were distributed.

"Encore ' 88 " was a great success. An audience of over 200 people attended, and the Library received over $\$ 600$. The program and performers were given rave reviews, and most importantly, enthusiasm was generated for "Encore '89." Word will spread concerning future concerts which should become better attended over the years. The appearance of a "big name" alumnus would also increase ticket sales significantly.

In retrospect, the money raised may not seem to justify the hours of preparation, but there are several benefits other than financial. The Conservatory Library received considerable exposure and publicity which is always welcome, and could pay future dividends. The relationship between the $\mathrm{Li}$ brary, Conservatory, and Development Office was strengthened through this experience. The Conservatory benefited by highlighting impressive alumni who can be the school's best advertising. Alumni were given an opportunity to perform at their alma mater, gain exposure, and convincingly demonstrate the value of their education. A new audience, largely drawn from the community, was introduced to the Conservatory and its many offerings. Only in retrospect was it realized how many people had benefited from this concert.

Plans are being made for "Encore '89." A newlyestablished Encore Concert Committee, consisting of the Conservatory librarian along with represent- atives from the University Development Office, the Conservatory's Publicity and Stage Management Offices, and the Conservatory Alumni Association, will oversee the organization of the next concert with hopes of smoothing out details. A calendar timetable will be created so that each year's committee is certain of all deadlines. The Conservatory's Library Committee will continue to assist in obtaining performers and assembling the program. Only with this university-wide cooperation can these concerts become a reality.

While music librarians should consider establishing such a concert, librarians in other disciplines can also involve their faculty in fundraising events. Departments in any of the performing arts possess obvious possibilities. But what about departments not normally associated with raising money at public events? There could certainly be a poetry reading presented by the English department, an art exhibit given by the art department, or a financial advising workshop sponsored by the business department. Well-known speakers in any subject can generate interest and raise significant funds. Such a speaker could be an alumnus or just a friend of the library and university.

There is no denying that fundraising events take detailed planning, require large amounts of time, and can cause several headaches. But librarians should not underestimate the positive image of libraries in the minds of faculty as well as the general public. During the initial planning of "Encore " 88 ," it was uncertain whether the necessary university-wide support would be received. In disbelief, a music professor stated emphatically that anyone not supporting the library and this concert would surely be opposed to the flag and apple pie. Sympathetic supporters are probably out there, but it is a librarian's responsibility to tap this resource through his or her own initiative. Fundraising through a concert or other event will take considerable effort and creativity, but its many rewards can make it all worthwhile.

\title{
Merchandising library services
}

\author{
By Luella Bosman Teuton \\ Coordinator, Library Services \\ South Florida Community College
}

Returning to the library profession after eight years in the business world has given me a new perspective. Librarians tend to look on our professions as service-oriented only, forgetting that we must also promote and "sell" our product. With funds being cut at many colleges and universities, librari- ans must be constantly demonstrating the value of library facilities and services. In the business world, if the public is not convinced of a product's worth they will not buy it. The end product in library services is not always visible to administrators. The services provided by libraries are often 
taken for granted and not valued until they are gone. Once lost, money and staff are not easily recovered. We as librarians must promote our expertise, services, and library materials as valuable products. Constant reinforcement is essential to continued support by administration and staff.

How does merchandising fit into the library's picture? Webster's Ninth New Collegiate Dictionary defines merchandising as "sales promotion as a comprehensive function including market research, development of new products, coordination of manufacture and marketing, and effective advertising and selling."

A survey will aid in determining what services and materials patrons are aware of and using. It will also allow an opportunity to ask for suggestions and ideas for new services. After conducting your market research, form a roundtable to discuss new ideas and suggest ways of implementation. Make sure all library staff are aware of new services.
Nothing creates a worse impression than staff who are not informed of changes and additions to library services.

Be open to new ideas. Try new methods of library promotion. Our bibliography rack in the student center has proven an excellent way to encourage students to come to the library. Students are drawn to the rack by brightly colored subject bibliographies covering areas of study taught on campus. This method allows us to reach students who might otherwise never make use of the library.

Educate administration, instructors, and students on the availability of new services and materials. Actively promote class usage of the library. Speak to local civic and business groups regarding library services offered. Groups such as these are an excellent source of additional funding. Promote, promote, promote! Keep in the public eye at all times. What is valued is not easily eliminated.

\section{Questioned imprints: A preliminary report}

The Antiquarian Booksellers' Association of America has been increasingly concerned with the growing number of questioned imprints which have been recently reported by a variety of recognized experts. For this reason they are publishing a list of imprints questioned to date. At the November 12 meeting of the Board of Governors an ABAA Committee on Questioned Imprints was appointed for the purpose of compiling pertinent details about such imprints and, where possible, obtaining copies of them. Members of the committee are Jennifer Larson (chair), John Curtis, Elisabeth Woodburn, Thomas Taylor, and Dorothy Sloan.

The resulting register of questioned imprints will include in its scope any printed item which is a reprint, facsimile, or fabrication that might be mistaken for a genuine original. The list is available from the ABAA, 50 Rockefeller Plaza, New York, NY 10021, but it represents only the beginning of an ongoing project. Additional bibliographical information, locations, or corrections regarding any item on the list would be appreciated.

The Committee is using the term "fabrication" to refer to an imprint of which no genuine copies are presently known. On the advice of legal counsel the phrase "alleged fabrication" is used in the list. The term "facsimile" will be applied to an exact copy of a genuine original. The term "reprint" indicates an imprint which in general follows the appearance of the original but is not an exact imitation. Owners of questioned imprints of which recognized originals exist are advised to take steps to authenticate their copies, if possible by comparison with a genuine copy. Only in the case of alleged fabrications should all copies be treated with suspicion.

The ABAA hopes that anyone who has knowledge of any questioned imprint will report it to them. Plans to make the results of this process generally available are being formulated. Inquiries about individual items are welcomed by the Committee and should be addressed to Jennifer S. Larson, Chair, ABAA Questioned Imprints Committee, c/o Yerba Buena Books, 882 Bush Street, San Francisco, CA 94108; (415) 474-2788. Any information regarding the source of any questioned imprint on the list should be referred to John $\mathrm{R}$. Curtis Jr., Chair, ABAA Ethics Committee, The Bookpress, Ltd., P.O. Box KP, Williamsburg, VA 23187.

In regard to library thefts, ABAA president Michael Ginsburg has appointed Barbara Rootenberg the ABAA's national security officer. Rootenberg will be in charge of the establishment of a new security system for rare book and manuscript thefts. If you were a victim of a theft, please notify Rootenberg at P.O. Box 5049, Sherman Oaks, CA 91403. Copies of reported losses will be mailed monthly to all members of the ABAA and the ILAB. Prompt notification will protect members from receiving stolen property unwittingly and may lead to the recovery of the material by its rightful owner.

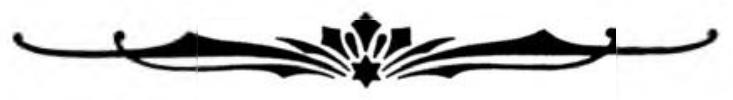

